\title{
Traditional Games versus Digital Games: Which is superior?
}

\author{
R Rahutami ${ }^{1}$, S Suryantoro ${ }^{2}$, M Rohmadi $^{3}$ \\ $\{3$ mamik@unikama.ac.id\} \\ ${ }^{1,2}$ Universitas Kanjuruhan Malang, Indonesia \\ ${ }^{3}$ Universitas Sebelas Maret, Surakarta, Indonesia
}

\begin{abstract}
The purpose of this study is to describe the advantages of traditional games compared to digital games in adolescent personality development. The method used is descriptive qualitative. The source of research data is the game activities of teenagers, both playing traditional games and digital ones and the various libraries about games. The results of the study show that traditional games are superior to digital games, especially the formation of adolescent characters as individuals and community members. Traditional games further develop the potential and health of adolescents comprehensively, whereas the digital games hone skills more cognitive and more affective than those ones. The results of this study are needed to provide understanding to the parents, the teachers, and the government in providing students learning facilities and regulation.
\end{abstract}

Keywords: traditional games, digital games, superior

\section{INTRODUCTION}

The phenomenon of playing the game with teenagers in Malang, Indonesia has experienced a shift. Traditional games, for example Gobag Sodor, engklek, petak-umpet, bentengan, bek thor are increasingly difficult to find in teenage games. The teenagers prefer carry their mobile phones and play games contained therein, such as mobile legend, PUBG, and free fire. The tendency of digital games raises pro-contra in society, between the cultural values and the technological modernization.

The role of the game in personality development has been recognized by learning experts. Montessori's view of pleasant learning influences cognitive, social, and personality outcomes [1]. The game develops skills, learns to get along, learns to solve problems, and learns to control emotions [2]. These skills are not taught at school but can be learned through experience only. Fun games can train positive emotions so that they can nourish the body and improve the quality of life [3]. Various studies of the impact or influence of the game have been made. The impact of the game on improving physical, mental, attitude, and mental health of the community have been carried out by Dehkordi [4]. Vlachopoulos and Makri stated that simulations and video games have a positive impact on learning goals [5]. More specifically, the study of Stojanovska, Malinovski, Connell, and Trajkovik states that different games have an impact on learning satisfaction, and significantly impact education outcomes [6]. Other research focuses on the role of traditional games on character education. Nugrahastuti, et al. [7]; Saputra and Ekawati [8] stated that traditional games shape the character of early childhood, both cognition, 
psychomotor, and affection. The traditional games are also the means of preserving the cultural arts [9].

The main problem that needs to be studied is the influence of traditional games and digital games. Tatli states that the preference of games not related with gender, and parents' education level[10]. Arias explains that video games have positive effects, on cognitive aspects, but also potentially negative acts of hostility, addiction, parenting patterns, and teacher behavior [11]. The role of teachers and parents is needed to direct children and accompany children [12]. Understanding the two types of games is needed. This research aims to compare traditional games and digital games.

\section{RESEARCH METHOD}

This research is a qualitative comparative analysis of the advantages of traditional games and digital games. The data source of this research is traditional games in the city and digital games played by teenagers in Malang. Data collection was carried out by observing the teenagers' play activities and the literature studies on traditional games and digital games.

\section{RESULTS AND DISCUSSION}

Traditional games originated from the previous generation to the next generation. The game has various functions and messages. The character of a traditional game is fantasy, recreation, sports, and also practicing life in society, practicing skills, practicing modesty, honesty, and dexterity. The aspects of traditional games include physical, psychological, and social aspects [13]. The form of a traditional game includes a physical game, children's songs, puzzles, a play with objects, and role-playing [14]. Digital games are resulted by technological modernization. The character of a digital game needs modern devices, both computers and mobile phones, and internet networks. The digital game requires high concentration. This concentration causes the player to ignore the environment and no contact with the environment cause anxiety or mental health problems [15]. Based on observations, it was concluded that teenagers played more digital games than traditional games. The factors influenced by the trend of playing digital games, friendship, facilities, and pleasure. The equations of traditional gameplay and digital games describe in table 1 .

Table 1. Equations of traditional games and digital games

\begin{tabular}{llll}
\hline Aspects & Traditional game & Digital game \\
\hline Emotions & playful & \multicolumn{1}{c}{$\begin{array}{c}\text { playful } \\
\text { enthusiastic }\end{array}$} \\
Cognition & critical & critical & creative \\
& & $\begin{array}{l}\text { creative } \\
\text { teamwork } \\
\text { Cooperation }\end{array}$ & discipline \\
Value & honest & teamwork \\
& & discipline \\
\hline
\end{tabular}

Table 1 shows the similarities of aspects in traditional game activities and digital game. The concept of the game which is intended to bring excitement to the players. The enthusiasm of the players urgent for the success of players winning the game. In the gobag sodor game, the player must be enthusiastic to touch the opponent to be able to defeat the opponent. Similarly, the 
$P U B G$ game requires players to enthusiastically try to avoid enemy attacks and attack the enemy.

Even though it has the same aspects, the embodiment of aspects is not always the same. Aspects of cognition in traditional games are more honed on critical thinking that still prioritizes respect for opponents. Although trying to defeat the opponent, the method used does not leave the ethics of humanity. On the other hand, in digital game games that are set up in the form of animations or cartoons, the human element is more ignored. Aspects similar to aspects of cognition are collaboration. In traditional games, players are always in a position as team members who must hold the team work solidly to win the game. While in digital games it is possible that players can play single. In this case, the traditional game is better able to teach players to cooperate, communicate, and respect their opponents..

Comparison of traditional games and digital games shows many differences. The following table 2 . shows the difference between the two types of games.

Table 2. Differences in traditional games and digital games

\begin{tabular}{|c|c|c|c|}
\hline Aspects & Traditional Game & & Digital Game \\
\hline Physical & $\begin{array}{l}\text { real activity } \\
\text { gestures }\end{array}$ & & $\begin{array}{l}\text { virtual activity } \\
\text { finger movements }\end{array}$ \\
\hline Tools & natural materials & & special tools \\
\hline Interaction & direct contac & & undirect contact \\
\hline Contact & physically contact & & virtual contact \\
\hline Effects & recreation & addicted & \\
\hline Activity & sport & & conflict \\
\hline & simulation & war & \\
\hline Value & inheriting cultural & & eksclusive \\
\hline
\end{tabular}

The different aspects of traditional games and digital games indicate weaknesses and strengths. It is possible, traditional games are superior to digital games, and vice versa. However, overall it can be concluded that traditional games are superior to digital games.

The game usually requires a tool, for example, bek uses stones, using a piece of tile (kreweng). These tools are very easy to find around the house or field that is a playground. In addition, the prices of the tools used for traditional games are relatively cheap. Not so with digital games that require hardware and software at relatively expensive prices. The provision of tools and facilities (internet networks) often creates several problems. For example, the children try to get money to buy data packages in various ways. In economically capable children because they are facilitated by parents, the provision of fund package funds and even cell phones is not a problem. Not infrequently, children steal money from other people or their parents to be able to buy data packages or cellphones. Another action is to force parents to provide the game tools and facilities. This action is an act that is not commendable.

With regard to the tools and processes of play, traditional games move the limbs as a whole, for example through the activities of running, jumping, or clapping while making a move on the game. Instead of the digital games prioritize the fingers movements and eyes fixation. Optimizing body movements makes the body healthier than the movements of digital games such as PUBG or mobile legend.

The communication is an important thing in establishing interaction. Educating efforts cannot be solely through formal education. The effective communication is easy to learn through play activities because real interaction requires communication skills. The communication skills in games can manifest in the addition of vocabulary, the courage to communicate, and respect 
for opponents of speech [16]. Traditional games and digital games require interaction with members in group games. However, both have differences. Interactions in traditional games are more direct contact. This direct contact requires visual contact, body, and speech contact. Meanwhile, digital games are more on speech contact. For example, the PUBG game only requires audio speech. Visual contact is only found in certain types of games. If observed, the language used as a communication tool is a language that is coarse, full of invective, because of irritation towards the party members who are not in accordance with the wishes of other players. Communication is done with the aim of regulating the behavior of other players who are not necessarily willing to be led by other members.

Digital's contacts that occur are also virtually. Digital games done through computers and mobile phones, the contacts are virtual. Unlike traditional games that require physical contact. In clash or hide and seek games, the players must be in the same place and physical contact occurs. The physical contact that occurs is carried out by the player while still paying attention to the safety factor of the team members and members of the opposite party. This concern is an educational value in interaction in society [17].

The game causes various psychological effects. In general, many traditional games provide recreational effects in the form of feeling happy, full of challenges and exercising body muscles. As can be found in the game, teenagers feel enthusiastic about winning the race. Enthusiasm is, of course, a joyful effect. Play activities train the muscles of the body so that it can restore the body's functions that have been disrupted. The end of the game can lead to feelings of satisfaction and physical health of the body. This is different from the effects of digital games. Digital games also provide fun and challenges overcoming various problems provided by programmers. The fun is obtained by the player when they get a victory. Victory is a challenge that demands the achievement of game goals. These challenges make players feel dissatisfied if they get defeat. This dissatisfaction makes the game player addicted to achieving victory, and a victory that results in additional points demands to always play the game. This addiction results in neglect of responsibility for the obligation of adolescents to do learning tasks, help parents, even socialize with the community [18].

Negative things that arise in digital games are caused by the types of digital game activities. PUBG game, mobile legend, free fire contains activities to resolve conflicts in an event, including battles or battles. Fighting and battle settings put pressure on mentally. Defeat makes you feel sad and status as a loser. Conversely, traditional games are a sport. All activities of moving the limbs result in the freshness of the body and thoughts. Traditional game activities are also in the form of simulations of everyday life, for example, playing cooking. Children try to imitate and are created with natural ingredients to be served in the dishes they make. This simulation effect can activate the power of innovation and children's creation in their adult years.

Traditional games also elevate cultural values through kid songs that have cultural values that contain implied messages, for example, the song cublak-cublak suweng. The song was intended to bring children closer to the Javanese cultural environment and become an introduction to a game that tests team agility and harmony. In contrast, digital games build more exclusive groups in children [19]. Digital game players are always in a special group that doesn't invite everyone to join the team. Players are usually formed from friendships or special groups. The positive side of the PUBG game is to build a spirit of corruption in overcoming problems. In adulthood, players are trained to tolerate building. 


\section{CONCLUSSIONS}

The traditional games have superior value than digital ones. It is necessary to notify and assist the children to choose the type of game. Inaccurate selection of the games can cause various adverse effects on the young generation.

\section{REFERENCES}

[1] Lillard A S 2007 Playful Learning and Montessori Education s Am. J. Play 5 157-86

[2] Gray P 2013 Play as Preparation for Learning and Life An Interview with Peter Gray Am. J. Play 5 271-92

[3] Goldstein J 2012 Play in Children'S Development, Health and Well-Being (Brussels)

[4] Dehkordi M R 2017 The Educational Impact of Traditional Games: the Role of Zurkhaneh Sport in Educating Children Int. J. Sci. Cult. Sport 5 134-9

[5] Vlachopoulos D and Makri A 2017 The effect of games and simulations on higher education: a systematic literature review vol 14 (International Journal of Educational Technology in Higher Education)

[6] Vasileva-Stojanovska T, Vasileva M, Malinovski T and Trajkovik V 2014 The educational prospects of traditional games as learning activities of modern students Proc. Eur. Conf. Games-based Learn. 2 746-59

[7] Nugrahastuti E, Puspitaningtyas E, Puspitasari M and Maret U S 2012 Nilai-Nilai Karakter Pada Permainan Tradisional Pros. Semin. Nas. Inov. Pendidik. Inov. Pembelajaran Berbas. Karakter dalam Menghadapi Masy. Ekon. ASEAN Dari 265-73

[8] Saputra N E and Ekawati Y N 2017 Meningkatkan Kemampuan Dasar Anak Tradisional Games in Improving Children' S Basic Abilities J. Psikol. Jambi 2 48-53

[9] Wulansari B Y and Ponorogo U M 2017 Jurnal Ilmiah Pendidikan PraSekolah dan Sekolah Awal 1 1-11

[10] Tatli Z 2018 Traditional and Digital Game Preferences of Children: A CHAID Analysis on Middle School Students Contemp. Educ. Technol. 9 90-110

[11] Arias M 2014 Dear Esther - The Chinese Room 1 49-69

[12] Panahi S 2016 Role of parents, Teachers, and Community in Adolescents ' issues ROLE OF PARENTS, TEACHERS , AND COMMUNITY IN ADOLESCENTS ` ISSUES

[13] Baierschmidt J 2013 A principled approach to utilizing digital games in the language learning classroom Jaltcall J. 9 307-15

[14] Belajar K, Anak P, Berk L E, Kunci K and Village E G 2007 Building children's character through traditional games $87-94$

[15] Skoric M M, Teo L L C and Neo R L 2009 Children and Video Games: Addiction, Engagement, and Scholastic Achievement CyberPsychology Behav. 12 567-72

[16] Hong J C, Ceng C L, Hwang M Y, Lee C K and Chang H Y 2009 'Assessing the educational values of digital games J. Comput. Assist. Learn. 25 423-37

[17] Ailwood J, Dakich E, Robbins J and Rivalland M P 2007 Book Reviews: The Excellence of Play, a Guide to Developing the ICT Curriculum for Early Childhood Education, Doing Your Early Years Research Project: A Step by Step Guide The Excellence of Play , 2nd ednMoylesJanet(Ed.), 2005Maidenhead: Open Unive vol 8

[18] Granic I, Lobel A and Engels R C M E 2014 The benefits of playing video games Am. Psychol. 69 66-78

[19] N.K. Juliantari, I.K. Sudarsana, N.K. Sutriyanti, I.N.T. Astawa, I.D.A.H. Putri, and K. Saddhono. "Educational Games Based in Information Technology as Innovation 
Evaluation Activity in Learning." In IOP Journal of Physics: Conference Series, vol. 1114 no. 1, p. 012041. IOP Publishing, 2018. 